\section{特集=医療と高分子 II}

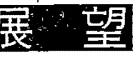

\section{医療用ディスポ製品}

蔵 田 元 二*

はじめ汇医療用ディスボ製品の概略，発達の要因， 現状などをとりまとめた概論を簡単に説明し，各論と して現在わが国で普及率の高い輸血，輸液セット，注 射針，注射筒，カテーテル類，血液バック括よび血液

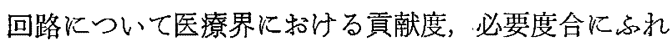
るとともに製品の解説をこころみた。つぎに安全性の 立場から，医療用プラスチック材料の改良，開発の参 考にな机ばと考光，医療用ディスポ製品で最近わが国 で問題化した項目を列挙し指摘した。最後に医療用と しての目標設定したプラスチック材料の開発が今後は 必要になり，そらいう時代がくることを要望した.

\section{1.はじめに}

総合医療産業が脚光を浴びはじめ, 約 10 年前梴 生した $\mathrm{ME}$ 産業に加光，医療用高分子産業はディス ポ製品分野で市場が急速に開け始めた。一兆円をはる が超光た医薬品に比べて医療用具産業は少なくな く，45 年の生産額は 1,500 億円にすぎない.ところ が医療労働力の不足や，医療水準の向上により $\mathrm{ME}$ 機 器やディスポ製品の需要は今後，急速に伸び 50 年に

\footnotetext{
* Motoji Kurata 株式会社日本メディカル・サプ ライ(739-04 広島罧佐伯郡大野町下更地 1990) 常務联綿役

Medical Disposable Products
}

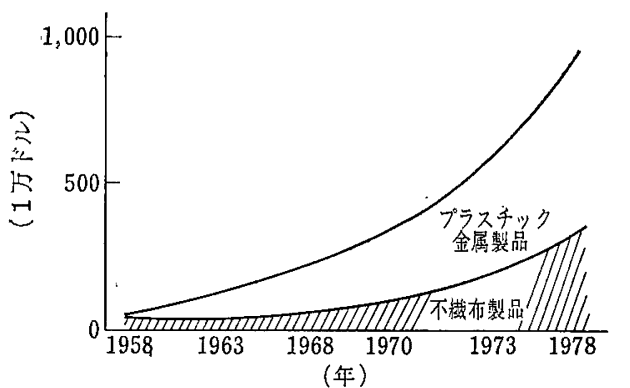

第 1 図医療用ディスポーザブル製品の素材別 マーケット構成（米国）

出所: Mcgraw-Hill 資料より NRI 作成

は 5,000 億円をこ党るとの予測も出始めている、ディ スホ製品は比較的小物が多く, 治療, 検查用器具類, 病室患者用製品に分類でき，盛生材料には不織布が使 用さ机始めた。治療用器具以対象および技法によって 種類が多く，医師の好みに応じての政良が加兄られた 製品も多く数10万以上もあると思われるが，従来材料 は金属，ガラス，ゴムなどでつくられていたが，急速 にプラスチック化されてきた。 これらがディス榑製品 と呼ばれ「リ・ューザブル」に対する言葉としてディス ポーザブル，すなうらち、随時使党る」といら意味であ り，滅菌され，状態を持続される包装をし，使用し捨 てるものであるから only one use の表現が適当とも 思われる，ディスポ製品の普及の要因は院内感染の防 止であり，省力化である，普及に伴い生産量の增加が 起こり，俆々にではあるが規格づけが始まり，小異を 捨てて多品種少量生産から大量生産方式に变化が起こ り，規格統一による経済性の向上もみられはじめてい る. ディスボ製品は第二次大戦で戦時医学としてアメ リカで発達した。 その後, アメリカ医療に大影響を与 えたメディケア法案成立により急速に伸び世界最大の 消費市場になり，すで第二段階を迎方，単品使用か ら治療目的により必要品をセット化した製品が普及の 段階にある。わが国では，33 年ごるより輸血セット の使用に始亲り，その後輸液セット・注射針·注射筒 と進々数種類のものを除いては普及率はいまだ高くな い.これは、リューザブルがいまだ安何であり，健 保適用外であるなど 経済上の問題が 主と考学られる が，品質，安全位対する不安もある。しかし，徐々で は西るか，年々その数を增し，最近では 200 種以上も あるといわれている。

\section{2. 主なディスポ製品}

\section{2-1. 輸血・輸液セット}

従来，リンゲル液などの薬液を多量に注入する場合 にはガラスのイルリガートルルゴム管を連結し先端に 


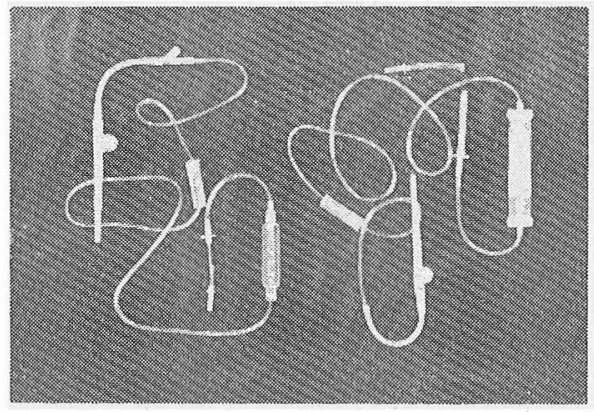

第 2 図輸血, 輸液七, 卜

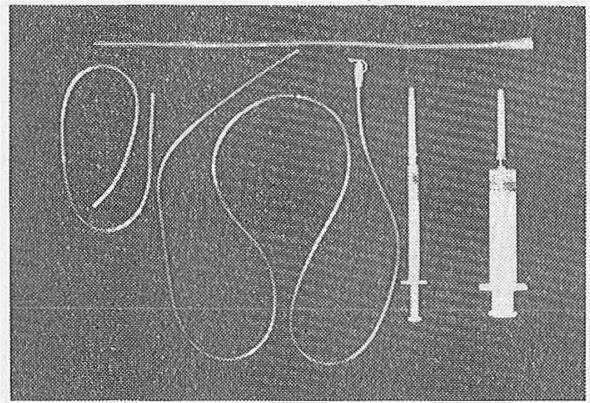

第 3 図 注射器およびカテーテル

静脈針を付けて使用していた。この方法は，一度使用し たものをくり返して使用するので洗浄, 組立, 隇菌が 必要で不能率玉た洗海隇菌の不借による障害が多発し ていた。輸血に佂ける再使用セットとディスポセット の副作用の此較は $21.8 \%$ と $6.7 \%$ で有意の差がみら れている．輸血と㡏夜セットは似通った構成であり， ゴム管が軟質塩化ビニルにとって変わり, 部品には塩 化ビニル，ポリプロピレン， ABS，ゴムなどが使用さ れている.主として塩化ビニルが使用されているのは 透明，柔㳄，耐熱性であり成形加工がよく安価である ことによる，需要量は增加の一途をたどり月産 450 万 セットと考学られる.

\section{2-2. 注射針および注射筒}

35年ころより $\mathrm{EO}$ ガス隇菌装置の完成を契機として ディスポ針の生産が本格化した，針もとはポリプロピ レンまたはポりアセタールでステンレス針が圧入また

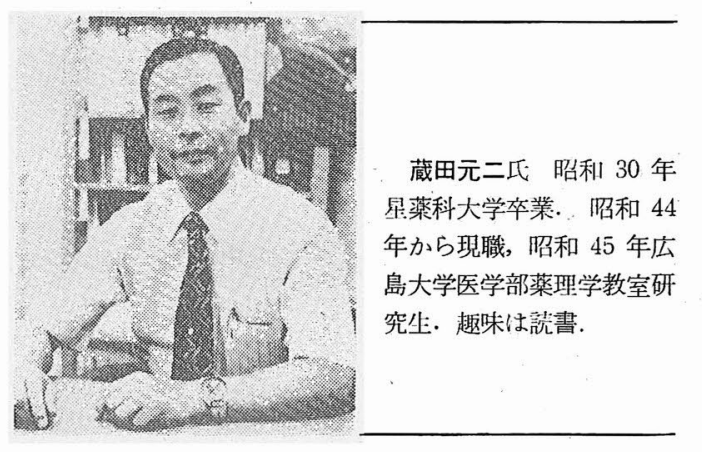

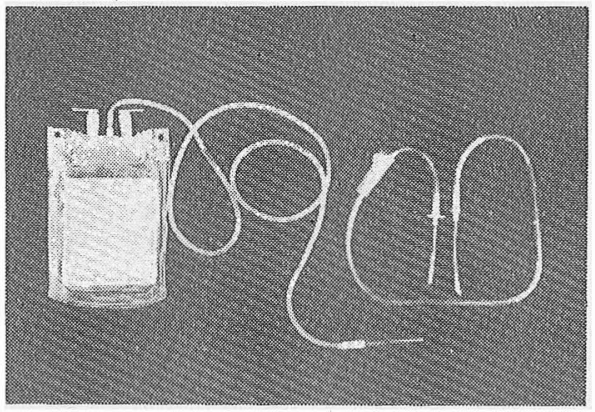

第 4 図 血液バックおよび採血セット

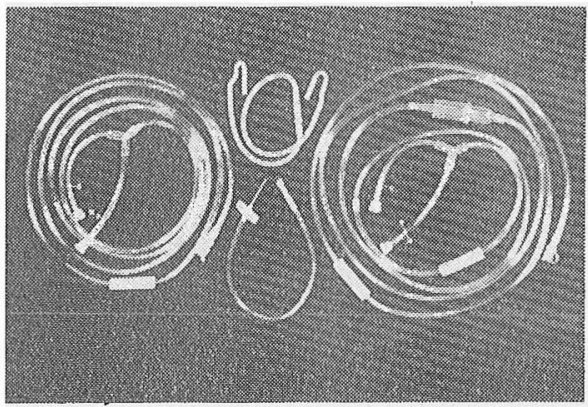

第 5 図 血液回路

は接着してつくられている，注射筒はポリプロピレン が圧倒的で，一部ポリスチレンを用いたものもある。 内筒の先端にはゴムの吸子がつけてあるが，海外で は，やや柔らかみのある樹脂で四子もつくられ始めて いる. 最近伸び率が高く，生産量はうかみにくいが注 射針 2,000 万本，注射筒 300 万本月産と推定される.

\section{2-3. カテーテル類}

従来はゴム製であったが，プラスチックの使用によ り新規製品の開発が促進され，医学の進歩とあいまっ て期待される製品である. 種類も多く塩化ビニルがお もで，そのほかポリェチレン テフロシ シリコーン も使用され需要は好調である.

\section{2-4. 血液バッグ}

採血針と管招よび血液保存袋からなる．使用されて いるガラスびんは重い，破損しやすい，急速輸血がで きにくい，細菌污染の危険が大きいなど欠点が指摘さ れている，一方では血液は不足して特り，血液成分の 不必要なものまで輸血し患者に負担をかけることもあ る. そこで必要な成分を分離し，治療目的にあったも ののみ輸血することが叫ばれ，患者の安全と献血の有 効性を高めるものである.この目的には血液バッグは 最適で今後期待される製品である.

\section{2-5. 血液回路}

透析療法が腎不全の治療法としてわが国に導入され てから数年になり，臨床的にはほぼ確立され日常

(637 頁へつづく) 
子を利用した新しい投与法にのせ，上り精密に投与し よう，それによって1回の用量を下げ，副作用をる軽 減し，新たな応用例をる開拓しょらとか，本来，人間 の体内にある活性物質をそのような device でコント

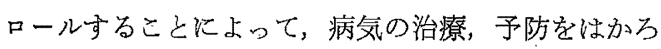
らといった試みに目が向けられ始めている。しかし， 医楽品の開発㴗必要となるデータは膨大なものであっ て，それに要する経費もまたばくだいなるのとなって きている.したがって，得られた高分子が製哓助剤と して，あるいは医薬品として，先発品に比べよぼど優 れた物でない限りは，まず日の目をみること㤝ないと
いわざるをえない，一方，高分子を利用した非経口的 な種々の device の場合は，そこに用いられる主薬が 小量で，上ほど高価なるのか，特殊な device なしに は作用点に薬を送り込むことがでさないとか，優れ た, 強力な生理活性のわりに情密な投与方法が困難 であるとか，いわ仂る難病を対照とした薬物のように 社会的にも必要度の高い上うな場合を除いては, 研究 的にはともかく，実用化は困難であるう．むらろん， 実用化された暁には, 薬の価格という点で, device そ のものにも正当な技術的評価がされなければならない ことはいらまでもない.

\section{（634 頁よりつづく）}

䛦療に応用されている。根本的な治療法がない現状で は一度透析療法が開始されれば定期的に永続した治療 法となる. 約 3,000 人が透析を受けているものと思わ れ，毎年 1 万人る腎不全患者が発生するとるいわれて いる. 回路は，動脈，静脈側回路からなり装置飞より， 若干の相違はあるが基本的には同㥞で, 軟質塩化ビ二 ルのパイプよりなり全体として $5 \sim 6 \mathrm{~m}$ の長されな る. 患者 1 人, 週 $1 \sim 2$ 回の透析が必要なので回路の 需要は大きく, 10 年後には $6 \sim 7$ 万人が使用すると の推定もあるので大型商品である.

\section{3. 安全性の立場から}

使用目的により，皮膚，組織または薬液と接触する ものなど用途によって安全性の検討が必要である。と くに医療注嫦之は違った価值観が必要であり，患 者の感受性も侾慮しなりればならない、ディスポ製品 で最近わが国で問題化したことを簡単に列挙し指摘す る.

第一飞有害性金属の危害である。一般に重金属系の 安定剤が使用され，しばしば衛生上の問題となった。 西鉛の毒性についても問題が提起されてきた，血液回 路についてはカルシウムの安定郕も問題となる。これ 性透析中に循環血液中にカルシウムが溶出し，血液凝 固を誘発する可能性があること炕よる。

つぎはフタル酸エステル系の可塑剤で，塩化ビニル を使用した製品から溶出し患者に異常がみられたとの 報告である. 有害無害両論があり今後の研究がまたれ
る. 涯加剤のすべての安全性がチェックできない現状 では最少限度にとどめるべきで，水による溶出のみな らず使用薬液などによる溶出体制を整えることも必要 である.

プラスチック表面に和计る血栓形成も大きな障害之 なりつつある. 血液の流体力学的問題, 材料の物理, 化学，電気的性質などいろいる因子が考觉られている が，血液回路の表面あらさも原因の一つ飞考兄られて いる. 仕上精度や金型，接続部位の凹凸なども重要で ある。

一般にプラスチックは静荷電しているので生産途上 麈が附着しやすく，ディスポ製品の異物の存在も指摘 され始めた。医療事故の原因にならないらちに早急に 解決すべきである。

ディスホ製品は無菌でかつ包装によってこの状態が 維持されなければ意味がない，ガスは通過するが微生 物は通過しない微小多孔性のフィルムの，開発が望委れ る.また，EO ガス隇菌による $\mathrm{EO}$ ガスの残留, 加熱 に上る生成物，これら生成物とガスの反応に上る二次 的生成物の解明も必要である.

\section{4.おわりに}

現在のディスポ製品は，はじわから医療を目的とし た材料はほとんぞなく，工業的使用されていたもの を医療用の用途使用してきたもので，これからは用 途の目標をきめ，それに適応する材料の開発が必要で ありそそらいう時代がくることを望むものである. 